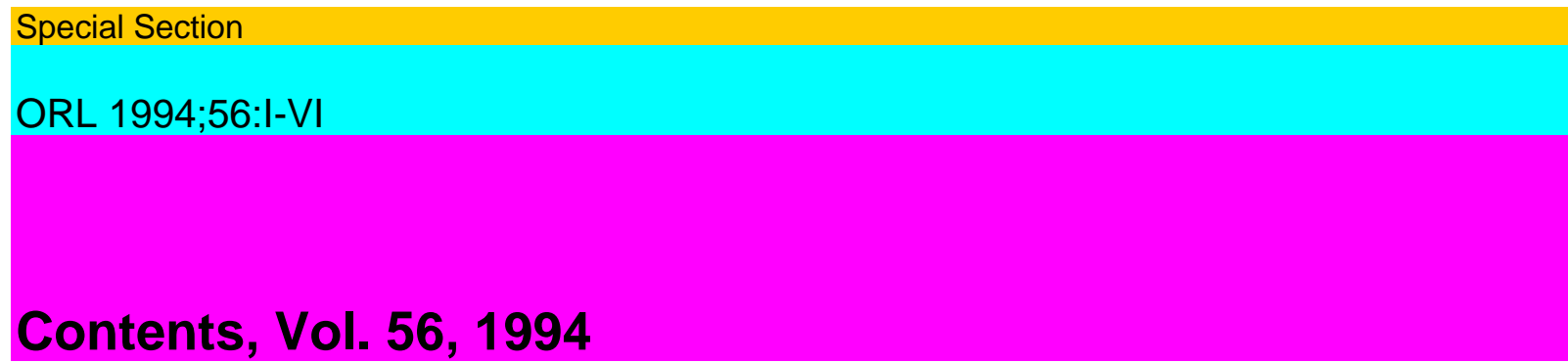

\title{
Contents Vol. 56,1994
}

No. 1

No. 2

\section{Original Paper}

Three-Dimensional Magnetic Resonance Imaging of the Inner 1 Ear in Idiopathic Sudden

Sensorineural Hearing Loss Albers, F.W.J.; Demuynck, K.M.N.P.; Casselman, J.W.

Clinical Features of Idiopathic Bilateral Sensorineural Hearing 5

Loss

Yagi, M.; Harada, T.; Yamasoba, T.; Kikuchi, S.

Immunological Approach to Ménière’s Disease: Vestibular 11

Immune Injury following Immune Reaction of the Endolym-phatic Sac Tomiyama, S.; Nonaka, M.; Gotoh, Y.; Ikezono, T.; Yagi, T.

Temporary Change of Compound Action Potential Amplitude 19

after Intense Sound Exposure

Homma, T.; Hasegawa, M.; Okamoto, A.; Yokoyama, K.; Tamura, T.

Effect of Gentamycin on Vestibular Dark Cells and Melano- 24 cytes: An Ultrastructural and

Cytochemical Study Yoshihara, T.; Kaname, H.; Ishii, T.; Igarashi, M.

Intraoperative Facial Nerve Monitoring in the Surgery of Cere- 31 bellopontine Angle Tumors:

Improved Preservation of Nerve Function Lenarz, T.; Ernst, A.

Oculomotor and Nystagmus Tests in Subjects with Strabismus 36 Wiklund, L.; Bergenius, J.;

Perols, O.

Postcaloric Nystagmus by Positional Change. 1. Study in 40

Normal Subjects Murofushi, T.; Mizuno, M.

Exogenous Heparin, Topically Administered, Aids the Remod- 45 elling of Connective Tissue in the Healing of Experimental Tympanic Membrane Perforations Hellström, S.; Spandow, O.

Correlation between Subjective and Objective Assessment of 51 Nasal Hyperreactivity Hallén, H.; Juto, J.-E.

Case Report

Multiple Sclerosis Presented Acute Hearing Loss and Vertigo 55 Sasaki, O.; Ootsuka, K.;

Taguchi, K.; Kikukawa, M.

Original Paper

Age-Related Degeneration of the Organ of Corti in Two 61

Genotypes of Mice Li, H.-S.; Hultcrantz, M.

Maturational Aspects of the Human Auditory Pathway: 68

Anatomical and Electrophysiological Findings Matschke, R.G.; Stenzel, C; Plath, P.; Zilles, K.

Distribution of Alpha-ANP in the Cochlea and the Vestibular 73

Organs

Yoon, Y.-J.; Anniko, M. 
Experiences with the New Audiant XA-II Implant and the 78

Behind-the-Ear (BTE) Device

Tange, R.A.; Zuidema, T.; Berg, R.v.d.; Dreschler, W.A.

Post-Caloric Nystagmus by Positional Change. 83

2. Study in Patients with Spinocerebellar Degeneration Murofushi, T.; Mizuno, M.; Hayashida, $\mathrm{T}$.

Submandibular Gland Excision: Short- and Long-Term

Complications

Hald, J.; Koks Andreassen, U.

An Objective Method to Record Changes in Nasal Reactivity 92 during Treatment of Non-

Allergic Nasal Hyperreactivity Hallén, H; Juto, J.-E.

Regional Low-Dose Interleukin-2 Immunotherapy of Lymph 96 Node Micrometastasis in a

Guinea Pig Tumor Model Bier, H.; Haas, I.; Koldowski, P.

Clinical Efficacy of Recombinant Human Granulocyte 101

Colony-Stimulating Factor in Patients with Head and Neck

Cancer

Tsukuda, M.; Furukawa, S.; Sawaki, S.; Kubota, A.

Chemotherapy for Recurrent Salivary Gland Malignancies: 105

Experience of the ENT Department of Turin University Airoldi, M.; Brando, V.; Giordano, C;

Gabriele, P.; Bussi, M.; Cortesina, G.

Book Reviews

60

Case Report

Pathology Spot

Papillary Adenocarcinoma Possibly Arising from an Intraduc- 112

tal Papilloma of the Parotid Gland

Shiotani, A.; Kawaura, M.; Tanaka, Y.; Fukuda, H.; Kanzaki, J.

Phenotype Switch and Activation of T Lymphocytes in 166

Patients with Allergic Rhinitis Karlsson, M.G.; Hellquist, H.B.

Case Reports

A Case Report of Sjögren's Syndrome with Repeated False 173

Cord Swelling

Ito, K.; Yuyama, S.; Yamashita, K.; Hiiragi, K.; Tsukuda, M.;

Ohishi, K.

Local Immune Response in Hyperplastic Lesions of the

Larynx

Kambic, V.; Gale, N.; Fischinger, J.

Statistical Analysis of Malignant Tumors Detected as the 161

Cause of Vocal Cord Paralysis Furukawa, M.; Furukawa, M.K.; Ooishi, K.

IV

Contents 
Reconstruction of the Anterior Laryngeal Wall with a Compos- 224 ite Graft of Demineralized Bovine Bone Matrix and Autogenous Perichondrium. An Experimental Study in Adult Rabbits Bean, J.K.; Verwoerd-Verhoef, H.L.; Verwoerd, C.D.A.

Epulis: A Clinicopathological Study of 120 Patients with 230

Emphasis on Recurrent Lesions Huang, X.; Berthold, H.; Laeng, R.H.

Case Reports

Primary Position Upbeat Nystagmus Localizing Value 236

Kanaya, T.; Nonaka, S.; Kamito, M.; Unno, T.; Sako, K.; Takei, H.

Occult Follicular Carcinoma Metastasizing to the Sinonasal 239

Tract

Yamasoba, T.; Kikuchi, S.; Sugasawa, M.; Higo, R.; Sasaki, T.

Rhinoorbital Mucormycosis: Surgical Aspects 244

Bessler, S.C.; Hailemariam, S.; Gammert, C.

No.S

Original Paper

Development of Melanosomes and Cytochemical Observation 247 of Tyrosinase Activity in the Inner Ear Fukazawa, K.; Sakagami, M.; Umemoto, M.; Senda, T.

Distribution of Hyaluronan in the Middle and Inner Ear. 253

A Light Microscopical Study in the Rat Using a Hyaluronan-Binding Protein as a Specific Probe Hellström, S.; Laurent, C; Yoon, Y.-J.

Na,K-ATPase Subunit Isoform Expression in the Guinea Pig 257

Endolymphatic Sac

ten Cate, W.-J. F.; Curtis, L.M.; Rarey, K.E.

Effect of $4 \mathrm{kHz}$ Tone Exposure on the Guinea Pig Inner Ear: 263 Relation in the Change of Cochlear Microphonics, Action Potential, Electrochemical Potential and K+ Ion Concentration Induced by Noise Exposure Sugisawa, T.; Nemoto, R.; Inada, N.; Yamamura, K.; Ishida, A. Directional Excitability of the Utricle: A Study by Thermo- 269

convective Stimulation Suzuki, M.; Aoki, M.; Kadir, A.

Functional Imaging of the Human Olfactory Cortex by 273

Magnetic Resonance Imaging

Koizuka, I.; Yano, H.; Nagahara, M.; Mochizuki, R.; Seo, R.;

Shimada, K.; Kubo, T.; Nogawa, T.

The Nasal Reactivity in Patients with Nasal Polyps 276

Hallén, H.; Graf, P.; Juto, J.E.

Methotrexate, Vinblastine, Epidoxorubicin, and Bleomycin as 279 Second-Line Chemotherapy for Recurrent and/or Metastatic Squamous Cell Carcinoma of the Head and Neck Gebbia, V.;

Valenza, R.; Testa, A.; Borsellino, N.; Cannata, G; Restivo, S.; Speciale, R.; Ingria, F.;

Spadafora, G.; Gebbia, N.

Crystallization Test for the Detection of Head and Neck 283

Cancer

Gulati, S.P.; Sachdeva, O.P.; Sachdeva, A.; Adlakha, R.P.; Kakkar, V.

Gastroesophageal Reñux Disease and Laryngeal Symptoms. 287 Is There Really a Causal

Relationship? Kjellén, G; Brudin, L.

Case Reports

Primary Tuberculosis of the Nasopharynx with Erythema 291

induratum of Bazin 
Yagi, M.; Kawabata, I.; Izaki, S.; Hosako, Y.

A Case of Behçet's Disease with Otologic Symptoms

Igarashi, Y.; Watanabe, Y.; Aso, S.

Choristoma of the Nasopharynx 299

Tahara, T.; Imate, Y.

Sinusitis Associated with Disorders of Visual Acuity 302

Sato, H.; Tsukuda, M.; Mochimatsu, I.; Furukawa, M.; Sawaki, S.

No. 6

Original Paper

Effects of Prostacyclin on Hearing Recovery after Repetitive 305

Noise and on Histomorphology of the Inner Ear in the

Guinea Pig

Michel, O.; Walger, M.; Schrott-Fischer, A.

X-Ray Microanalysis and Ion Microscopy of Guinea Pig 310

Cochlea and Kidney after Cisplatin Treatment Saito, T.; Aran, J.-M.

Comparative Ototoxicity of Cisplatin during Acute and 315

Chronic Treatment

Saito, T.; Aran, J.-M.

Postcaloric Nystagmus by Positional Change and Other 321

Neurootological Findings Murofushi, T.; Mizuno, M.; Hayashida, T.

$\mathrm{V}$

Analysis of Gait in Patients with Peripheral Vestibular 325

Disorders

Ishikawa, K.; Edo, M.; Yokomizo, M.; Terada, N.; Okamoto, Y.;

Togawa, K.

Analysis of the Prognosis and the Recovery Process of Pro- 331

found Facial Nerve Paralysis Secondary to Acoustic Neuroma

Resection

Kunihiro, T.; Kanzaki, J.; Yoshihara, S.; Satoh, Y.

Correlation between Objective Nasal Mucosal Swelling and 334 Estimated Stuffiness during

Long-Term Use of Vasoconstrictors Graf, P.; Juto, J.-E.

Case Reports

Auditory Brainstem Responses in Leptomeningeal Metastatic 340

Spread. Presentation of 2 Cases

Funai, H.; Hayase, A.; Kitahara, N.; Hosako, Y.

Hypopituitarism and Hyponatremia in a Case with Nasopha- 347 ryngeal Carcinoma Kokatsu, T.; Tsukuda, M.

A Delayed Teflonoma of the Neck Simulating a Thyroid Neo- 352

plasm

Wassef, M.; Achouche, J.; Guichard, J.-P.; Tran Ba Huy, P.

Announcements 351

Author Index 357

Subject Index 359

VI

Contents 